\title{
Wujud Campur Kode Takserumpun dalam Wacana Berita Daerah Harian Suara Merdeka
}

\author{
Mujid Farihul Amin \\ Fakultas Ilmu Budaya, Universitas Diponegoro \\ moejid70@gmail.com
}

\begin{abstract}
Language events that often occur in daily interactions are the mixing of a codel element of language into the codelelement of another language. These linguistic events in sociolinguistics are known as mixed codes. Based on the language of the source, the mixed code in the Suara Merdeka daily news discourse can be divided into two types, namely the cognate mixed code and the noncognate mixed code. In this paper, only the noncognate mixed code.

In the noncognate mixed code, between the source language and the target language have no relationship, both geographically and genetically. So, geographically these languages are used as an introduction to different political areas. Likewise seen from their kinship relations, the languages involved in interfering with the code are not related. The form of noncognate mixed code contained in Suara Merdeka's daily regional news discourse can be in the form of words, phrases, forms of baster, idioms, and clauses.
\end{abstract}

Keywords: mixedcode, noncognate, the discourse of regional news, Suara Merdeka.

\section{Intisari}

Peristiwa kebahasaan yang sering terjadi dalam interaksi sehari-hari adalah tercampurnya suatu kode/unsur bahasa ke dalam kode/unsur bahasa lain. Peristiwa kebahasaan ini dalam sosiolinguistik dikenal dengan istilah campur kode. Berdasarkan bahasa sumbernya, campur kode dalam wacana berita daerah harian Suara Merdeka dapat dibagi menjadi dua jenis, yaitu campur kode serumpun dan campur kode takserumpun. Dalam tulisan ini yang dikaji hanya campur kode takserumpun.

Dalam campur kode takserumpun, antara bahasa sumber dan bahasa sasaran tidak mempunyai hubungan, baik secara geografis maupun genetis. Jadi, secara geografis bahasabahasa tersebut dipergunakan sebagai pengantar dalain wilayah politis yang berbeda, Demikian pula dilihat dari hubungan kekerabatannya, bahasa-bahasa yang terlibat dalam campur kode itu tidak berhubungan. Wujud campur kode takserumpun yang terdapat dalam wacana berita daerah harian Suara Merdeka dapat berupa kata, frasa, bentuk baster, idiom, dan klausa.

Kata Kunci: campur kode, takserumpun, wacana berita daerah, Suara Merdeka.

\section{Pendahuluan}

Dalam interaksi sehari-hari, pasti terjadi berbagai peristiwa kebahasaan. Dari sekian banyak peristiwa kebahasaan yang seringkali terjadi adalah tercampurnya suatu kode/unsur bahasa ke dalam kode/unsur bahasa lain. Peristiwa inilah yang dalam sosiolinguistik dikenal dengan istilah campur kode. 
Ada banyak pengertian mengenai campur kode. Alwasilah (1985:56) mengetengahkan bahwa campur kode adalah peralihan dari satu dialek ke dialek lainnya. Jadi, tidak dibedakan antara campur kode dan alih kode. Berbeda dengan Alwasilah, Soewito (1985:76) dan Poedjosoedarmo (1986:68) memiliki pandangan yang sama, yaitu membedakan pengertian campur kode dan alih kode. Keduanya berpendapat bahwa perpindahan dari kode satu ke kode iainnya akan disebut alih kode bila perpindahan itu terjadi antarklauasa, sedangkan perpindahan kode yang terjadi seeara intraklausal akan memuncuikan campur kode. Menurut Nababan (1986:32) campur kode adalah pencampuran dua (atau lebih) bahasa atau ragam bahasa dalam suatu tindak bahasa (speech act atau discourse) tanpa ada sesuatu dalam situasi berbahasa itu yang menuntut pencampuran bahasa itu. Jadi, hanya kesantaian penutur dan/atau kebiasaan penutur yang dituruti. Kode dapat berwujud bahasa, diaiek, register, tingkat tutur, dan ragarn (Kridalaksana 1982: 87).

Kemunculan campur kode dalam tindak tutur sehari-hari memang sangat sulit dihindarkan. Dalam eraglobalisasi seperti sekarang ini, banyak diantara penutur suatu bahasa yang selain menguasai bahasa pertama juga menguasai paling tidak satu bahasa lain. Apalagi dalam wacana yang penulis jadikan objek tulisan ini.

Wacana berita yang penulis jadikan objek adalah wacana berita daerah yang ada di harian Suara Merdeka. Dalam wacana ini, biasanya dituturkan/berisi berita-berita dari berbagai daerah yang ada di Jawa Tengah. Berbagai daerah yang ada di Jawa Tengah, para penuturnya selain menguasai bahasa Indonesia mereka juga menguasai bahasa daerah, yaitu bahasa Jawa. Bahkan, selain menguasai dua bahasa itu, banyak juga penutur yang menguasai paling tidak satu bahasa asing (misalnya bahasa Inggris, Arab, Perancis, dan Cina).

Karena keadaan yang ada seperti yang penulis kemukakan di atas, munculnya campur kode dalam wacana berita daerah di harian Suara Merdeka tidak dapat dinafikan/dielakkan. Untuk itulah, pada artikel/tulisan ini dikaji wujud campur kode takserumpun dalam wacana berita daerah di harian Suara Merdeka.

Dalam campur kode tipe ini, antara bahasa sumber dan bahasa sasaran tidak mempunyai hubungan, baik secara geografis maupun genetis. Jadi, secara geografis bahasabahasa tersebut dipergunakan sebagai pengantar dalain wilayah politis yang berbeda, Demikian pula dilihat dari hubungan kekerabatannya, bahasa-bahasa yang terlibat dalam campur kode itu tidak berhubungan. 
Dengan demikian, dapat dikatakan bahwa penentu hubungan campur kode takserumpun adalah derajat keasingan bahasa-bahasa yang terlibat kasus tersebut, baik dari sudut geografis maupun genetis secara bersamaan. Sebagai contoh, bahasa Inggris dengan bahasa Indonesia, baik secara geografis maupun genetis kedua bahasa itu tidak berhubungan. Secara geografis, kedua bahasa itu masing-masing sebagai bahasa pengantar (bahasa nasional) di negara yang berbeda, Sedangkan secara genetis, bahasa Indonesia bukan merupakari varian dari bahasa Inggris atau sebaliknya,

Masalah utama yang akan dibahas dalam tulisan ini adalah apa saja wujud campur kode takserumpun dalam wacana berita daerah harian Suara Merdeka.

\section{Metode Penelitian}

Dalam penelitian ini, penulis menggunakan tiga tahapan strategis yang dikemas dalam metode penelitian, meliputi metode pengumpulan data, metode analisis data, dan metode penyajian hasil analisis data (Sudaryanto, 1993: 5).

Dalam pengumpulan data untuk penelitian ini, penulis menggunakan teknik simak dan teknik catat. Jadi, penggunaan bahasa yang ada dalam wacana berita daerah harian Suara Merdeka yang di dalamnya terdapat campur kode penulis amati dan kemudian data tersebut dicatat dalam kartu data untuk diolah dan dianalisis.

Data yang telah dimasukkan ke dalam kartu data kemudian pada tahap selanjutnya dianalisis. Penganalisisan data dilakukan dengan menggunakan metode normatif dan identitas. Hal ini perlu dilakukan untuk mengetahui jenis dan wujud campur kode yang ada dalam data tersebut. Setelah diketahui jenis dan wujud campur kode, data siap untuk disajikan.

Tahap ini merupakan upaya peneliti menampilkan wujud 1aporantertulis apa-apa yang telah dihasilkan dari kerja analisis yang telah dilakukan pada tahap analisis data. Dalam penyajian hasil analisis digunakan cara informal, yaitu dengan menggunakan kata-kata biasa tanpa menggunakan lambang-lambang.

\section{Hasil dan Pembahasan}

Dalam campur kode jenis ini, antara bahasa surnber dan bahasa sasaran tidak ada hubungan, baik secara genetis maupun secara geografis. Jadi, dilihat dari kekerabatannya, bahasa-bahasa yang terlibat campur kode dalam jenis ini sudah tidak berhubungan. Begitu puia secara geografis, bahasa-bahasa tersebut dipergunakan sebagai bahasa pengantar dalam wiiayah politis yang berbeda.

Penentu suatu kasus campur kode termasuk campur kode takserumpun adalah 
keasingan bahasa sumber dari bahasa sasaran, baik secara genetis maupun geografis.

Campur kode takserumpun dalam wacana berita daerah harian Suara Merdeka dapat berwujud kata, frasa atau kelompok kata, bentuk baster, dan idiom. Berikut akan diuraikan satu per satu disertai dengan data yang ada.

\section{Kata}

Campur kode takserumpun dapat terjadi antara lain karena adanya pemasukan unsur lain yang berupa kata. Pemasukan unsur berupa kata yangberasal dari bahasa asing berdasarkan data yang ada dalam wacana berita daerah harran Suara Merdeka berasal dari bahasa Inggris, Arab, dan Belanda.

Wujud campur kode takserumpun berupa kata yang berasal dari bahasa Inggris dapat dilihat pada data (1) - (6) berikut

(1) Resume acara itu disampaikan dalam pertemuan dengan DPC. (SM, 1-12-2001. XXIII).

(2) Output yang diharapkan dari peserta kursus adaiah menjadi embrio dalam rangka sosialisasi pelestarian lingkungan. (SM, 10-5-2001, XVlil).

(3) DKK lelah befupaya meminta tambahan baiituaii obat malaria sebanyak 30 liter untuk melakukan fagging di Wonokarto, Giripurwo, dan Wuryorejo (Kecamatan Wonogiri Kota), Praci (Pracimantoro), dan Singodutan (Selogiri). (SM, 10-3-2001, XVII).

(4) Bumh akan ditempatkan sebagai partner pengusaha dan pemerintah. (SM, 30-6-2001, XVII).

(5) Penelepon bersuara laki-laki, menurut dia, semuia mencari orang yang bertugas di bagian security, (SM? 30-9-2001, II).

(6) Kota Sala sekarang ini kekurangan guide. (SM, 10-4-2001, XVI).

Pada data (1) - (6) dapat dilihat adanya pemasukan unsur bahasa Inggris ke dalam bahasa Indonesia berupa kata, yaitu resume, output, fogging ,partner, security, dan guide. Unsur campur kode takserumpun berupa kata daribahasa Inggris berdasarkan data semuanya berkategori nomina seperti tampakpada data (1) - (6). Hal ini berbeda dengan unsur campur kode serumpun berupa kata yang dapat berkategori nomina, adjektiva, maupun verba.

Kata resume pada data (1) berpadanan dengan kata "ringkasan' daiam bahasa Indonesia. Pemakaian kata resume pada data (1) untuk menunjukkanbahvva penutur adalah orang yang berpendidikan cukup dan mempunyai hubungan luas. Hal ini sesuai dengan konteks data, yaitu dalain suatu forum pertemuan dengan pengurus partai politik.

Kata output pada data (2) mempunyai padanan kata 'hasil, luaran' dalam bahasa 
Indonesia. Kata output cialam konteks data (2) digunakan berkaitan dengan dunia pendidikan atau akademis yaitu kursus mengenai pelestarian lingkungan. Demikian pula kat\& fogging pada data (3) digunakan dalam konteks data yang cukup mendukung, yaitu dalam bidang kesehatan. Hal ini ditunjukkan dengan adanya nama instansi dan nama obat, yaitu DKK (Dinas Kesehatan Kabupaten) dan obat malaria. Kata fogging mempunyai padanan kata 'penyemprotan' dalam bahasa Indonesia.

Pada data (4) kata partner berpadanan dengan kata 'mitra' dalam bahasa Indonesia. Kata partner digunakan untuk mengangkat citra buruh dan untuk menunjukkan bahwa buruh bukanlah sapi perahan pengusaha dan pemerintah, Karena dalam bahasa Indonesia sudah ada padanan kata yang tepat untuk kata partner, maka gunakanlah padanan kata tersebut, yaitu 'mitra'.

Kata security dan guide pada data (5) - (6) berpadanan dengan kata 'keamanan' dan 'pemandu' dalam bahasa Indonesia. Pemakaian kata security pada data (5) karena tempat yang memakai kata tersebut (hotel dan mal Ciputra) tidak hanya dikunjungi orang Indonesia tetapi juga orang asing atau penutur nierasa lebih bangga memakai kata yang berasai dari bahasa asing. Pemakaian kata guide pada data (6) sesuai dengan konteks lokasi pada data tersebut, yaitu Kota Solo, salah satu daerah tujuan wisata yang banyakdikunjungi tuns mancanegara. Pemakaian kata guide pada data (6) sebetiarnya tidak mutlak karena kata tersebut sudah ada padanannya dalam bahasa Indonesia yaitu 'pemandu'.

Dari uraian di atas, kata dari bahasa Inggris, yaitu resume, output, fogging, partner, security, dan guide pada data (1) - (6) identik dengan kata 'ringkasan', 'hasi!', 'pengasapan', 'mitra','keamanan', dan 'pemandu'. Oleh karena itu, data (1) - (6) dapat diubah menjadi (1a) - (6a) berikut.

(1a) Ringkasan acara itu disampaikan dalam pertemuan dengan DPC.

(2a)Hasti yang diharapkan dan peseria kursus ada)ah menjadi embrio dalam rangka sosialisasi pelestarian lingkungan.

(3a) DKK telah berupaya meminta tambahan bantuan obat malaria sebanyak 30 liter untuk melakukan pemyemprotan di Wonokarto, Giripurwo, dan Wuryorejo (Kecamatan Wonogiri Kota), Praci (Pracimantoro), dan Singodutan (Selogiri).

(4a)Buruh akan ditempatkan sebagai mitra pengusaha dan pemerintah.

(5a) Penelepon bersuara laki-Iaki, menurut dia? semula mencari orang yang bertugas di bagian keamanan.

(6a) Kota Sala sekarang ini kekurangan pemandu. 
Unsur campur kode takserumpun berupa kata dalam wacana berita daerah harian Suara Merdeka ada yang berasal dari bahasa Arab. Hal ini dapat dilihat pada data berikut.

(7) Menjelang dimulainya isiighotsah pengasuh Ponpes Miftahul Huda KH Su'ada membacakan tausiyatus siyaasah. (SM, 30-12001, XX).

(8) Seperti tahun-tahun sebelumnya. menyambut datangnya bulan Ramadan, Hotel Quality, Sala mengadakan berbagai acara untuk meramaikan syiar Islam. (SM, 30-11-2001, XVI).

(9) Ahmad Yusuf Sujianto dari PPP Kota Semarang menyatakan jika semua partai Islam menjalankan nilai agama secara kafah tak akan terjadi persoalan, (SM, 20-9-2001, XTTT).

(10) Sejumlah peneliti, tennasuk Munir Mulkan dan kawan-kawan, menilai para pengikut tarekat tak hanya mengajarkan praktek ibadah mahdhah. (SM, 30-7-2001, XVIII).

Pada data (7) - (10), terdapat kata-kata istighotsah, syiar, kafah, dan mahdhah yang berasal dari bahasa Arab. Kata istighotsah pada data (7) berpadanan dengan kata ${ }^{c}$ doa bersama ${ }^{r}$ dalam bahasa Indonesia. Kata ini digunakan oleh penutur yang mempunyai nilai-nilai kegamaan yang kuat. Selain itu, kata istighotsah lazim digunakan dalam lingkup pondok pesantren.

Pemakaian kata syiar pada data (8) berkaitan dengan masalah keagamaan yaitu datangnya bulan Ramadan yang merupakan bulan suci bagi umat Islam. Selain itu, penutur merasa kesulitan untuk mencari padanan kata yang tepat untuk kata tersebut dalam bahasa Indonesia sehingga penutur tetap menggunakan kata syiar.

Kata kafah pada data (9) berpadanan dengan kata 'menyeluruh' dalam bahasa Indonesia. Pemakaian kata tersebut untuk menunjukkan bahwa penutur mempunyai pengetahuan agama yang mendalam dan berasal dari komunitas tertentu. Pada data tersebut disebutkan bahwa penutur berasal dari salah satu partai di Indonesia yang berbasis Islam, yaitu Partai Persatuan Pembangunan (PPP).

Kata mahdhah pada data (10) berpadanan dengan kata 'pokok' atau 'wajib' dalarn bahasa Indonesia. Pemakaian kata mahdhah sesuai dengan konteks, yairu untuk menunjukkan bahwa kata tersebut lazim digunakan dalam lingkungan yang mempunyai nilai-nilai keagamaan yang cukup kuat.

Selain dan bahasa Inggris dan Arab, unsur campur kode takserumpun yang dijumpai dalam wacana berita daerah harian Suara Merdeka ada pula yang berasal dari bahasa Belanda. Perhatikan data (11) sampai (13) berikut.

(11) Dalam pledooi, penasehat hukum juga meminta keringanan hukuman terdakwa. (SM, 10-10-2001, XXIV).

(12) Secara de facto mereka bertugas di berbagai wilayah kecamatan. 
(SMJ0-12-2001, XVII).

(13) Ruilslag SLTP 20 dan SMU 10 di Jl. Gebangsari, Genuk, hingga kemarin masih belum dilaksanakan (SM, 30-3-2001, XIII).

Kata pledooi, de facto, dan ruilslag pada data (11) - (12) merupa-kan kata-kata yang berasal dari bahasa Beianda. Kata pledooi pada data (11) berpadanan dengan kata 'pembeiaan'. Pemakaian kata pledooi berkaitan dengan dunia hukum. Hal ini dapat dimengerti karena pedoman-pedoman hukum di Indonesia -baik hukum pidana maupun perdata - banyak yang mengacu ke Belanda. Dulu Indonesia dijajah oleh Belanda sehingga segala sesuatu yang berkaitan dengan masalah hukum, baik istilah-istilahnya maupun peraturan-peraturannya bersumber dari Belanda,

Kata de facto dan ruilslag pada data (12) dan (13) mempunyai padanan kata 'nyata' dan 'tukar guling' dalam bahasa Indonesia. Kata de facto biasa digunakan dalam kaitannya dengan masalah hukum, khususnya hukum ketatanegaraan. Pada konteks data (12) kata de facto digunakan dalam kaitannya dengan pembagian tugas dalam suatu wilayah kecamatan. Kata ruilslag digunakan dalam kaitannya dengan masalah hukum perdata. Pada konteks data (13), kata ruilslag digunakan untuk menunjukkan belum dilaksanakannya rencana tukar guling gedung SLTP 20 dan SMU 10 yang selalu terkena banjir kalau musim hujan.

\section{Frasa}

Selain berupa kata, wujud campur kode takserumpun dapat juga berupa frasa atau kelompok kata. Berdasarkan data, frasa yang merupakan unsur carnpur kode takserumpun hanya ada yang bertipe endosentrik, tidak ada yang bertipe eksosentrik. Campur kode takserumpun yang berwujud frasa dapat dilihat pada data berikut.

(13) Tourist police itu, kata dia; juga disiapkan bertugas di kawasan pariwisata, sehingga setiap saat mereka memberikan layanan yang bersifat segera. (SM, 20-2-2001, XIII).

(14) Cold storage ditempatkan di Blondo, dekat jalan raya Yogyakarta-Semarang. (SM, 10-8-2001, XV").

(15) Diperkirakan, kehadiran peserta itu tidak disampaikan tour operator yang memandu para pelaku bisnis pariwisata yang sudah sejak Kamis mengadakan pertemuan di Sala. (SM, 20-102001, XVIII).

(16) Prospeknya sampai sepuluh iahun ke depan masih terjadi over demand di pasar, sehingga harganya relatif stabil. (SM, 1-11-2001, XVIII).

Pada data (13) dan (16) di atas terjadi pemasukan unsur yang berbentuk frasa dari 
bahasa Inggris yaitu tourist police, cold storage, tour operator dan over demand, Frasa tourist police pada data (13) bertipe endosentrik yang koordinatif karena dapat dihubungkan dengan kata and "dan". Frasa tersebut mempunyai pengertian atau dalam bahasa Indonesia berpadanan dengan 'polisi wisata'. Frasa tourist police dimaksudkan untuk menunjukkan bahwa polisi wisata diperlukan di objek-objek wisata di Indonesia untuk memberikan layanan yang bersifat segera kepada para wisatawan. Pemakaian frasa tourist police dalam konteks data (13) untuk mempermudah pemahaman para wisatawan terutama yang berasal dari mancanegara.

Pada data (14), frasa cold storage termasuk frasa endosentrik atributif karena unsur-unsurnya tidak mungkin dihubungkan dengan kata and 'dan' atau or 'atau'. Frasa cold storage intinya storage dan atributnya cold. Frasa tersebut mempunyai pengertian 'ruang pendingin'. Dalam konteks data tersebut menggambarkan bahwa Pemda Jawa Tengah sudah mempunyai alat untuk menyimpan hasil-hasil pertanian supaya lebih tahan lama. Alat tersebut ditempatkan di Blondo, dekat jalan raya Yogyakarta - Semarang,

Frasa tour operator pada data (15) termasuk frasa endosentrik atributif dengan unsur inti operator dan atributnya tour. Frasa tersebut mempunyai pengertian 'biro wisata', atau 'jasa penyelenggara wisata' dalam bahasa Indonesia. Pada konteks data tersebut untuk menggambarkan biro wisata yang tidak memberitahukan terlebih dulu kehadiran para peserta dari negara lain kepada para pelaku bisnis pariwisata yang sedang mengadakan pertemuan di Solo. Karena tidak diberitahu, maka para pelaku bisnis pariwisata tidak mempersiapkan data-data secara lengkap untuk dipromosikan kepada para peserta dari negara lain.

Frasa over demand pada data (16) termasuk frasa endosentrik atributif dengan unsur inti demand dan atribut over. Frasa tersebut mempunyai pengertian 'lonjakan permintaan'. Frasa ini pada konteks data (16) menunjukkan kaitan antara lonjakan permintaan dengan kestabilan harga. Kalau terjadi peningkatan permintaan maka harga akan stabil atau malah bisa naik.

Karena frasa tourist police, cold storage, tour operator, dan over demand identik dengan 'polisi wisata', 'gudang pendingin', 'penyelenggara wisata', dan 'lonjakan permintaan', maka data (13) - (16) dapat diubah menjadi (13a) - (16a) berikut.

(13a) Polisi wisata itu, kata dia, juga disiapkan bertugas di kawasan pariwisata, sehingga setiap saat mereka memberikan layanan yang bersifat segera.

(14a) Gudang pendingin ditempatkan di Blondo, dekat jalan raya Yogyakarta- 
Semarang. (SM, 10-8-2001, XV).

(15a) Diperkirakan, kehadiran peserta itu tidak disampaikai penyelenggara wisata yang memandu para pelaku bisnis pariwisata yang sudah sejak Kamis mengadakan pertemuan di Sala.

(16a) Prospeknya sampai sepuluh tahun ke depan masih terjadi lonjakan permintaan di pasar, sehingga harganya relatif stabil.

Selain frasa endosentrik seperti pada data (13) - (16) ada juga frasa endosentrik yang di dalamnya terdapat preposisi seperti data berikut.

(17) Sutiatmoko dari Presidium Formas menjelaskan pejabat yang dipromosikan dengan perlakuari istimewa itu perlu menjalani fit and proper test. (SM, 10-3-2001, XVII).

(18) Menurut dia, penempatan pegawai seharusnya berdasarkan kompetensi dan kapabilitas, bukan like and dislike. (SM, 2001,XVIII).

(19) Karena keterbatasan dana, pelaksanaannya step by step. (SM, 30-10-2001, XV11).

(20) DPRD dinilai tidak memiliki sense of crisis. (SM, 30-7-2001, XIV).

(21) Beberapa tetangga membantu memasarkan door to door. (SM, 10-12-2001, XV).

(22) Dia mencontohkan sebagian besar sekolah kejuruan belum memiliki sarana dan prasarana up to date. (SM, 1-4-2001).

Frasa fit and proper test, like and dislike, step by step, sense of crisis, door to door, dan up to date pada data (17) - (22) merupakan frasa yang di dalamnya mengandung konjungsi atau preposisi. Frasa fit and proper test pada data (17) mengandung konjungsi and 'dan'. Oleh karena itu frasa tersebut termasuk firasa endosentrik koordinatif aditif. Frasa tersebut mempunyai pengertian 'uji kesiapan dan kelayakan' dan dalam konteks data (17) digunakan untuk menunjukkan bahwa pejabat yang dipromosikan harus melalui uji kesiapan dan kelayakan dulu.

Frasa like and dislike pada data (18) mempunyai pengertian 'suka dan tidak suka'. Frasa ini juga termasuk frasa endosentrik koordinatif aditif karena mempunyai dua unsur inti yaitu like 'suka' dan dislike 'tidak suka' serta konjungsi and 'dan'. Frasa like and dislike pada konteks data (18) untuk menunjukkan adanya penempatan pegawai berdasarkan prinsip 'suka dan tidak suka' tidak berdasarkan persaingan sehat dan kecakapan/kemampuan.

Pada data (19) frasa step by step mempunyai pengertian 'tahap demi tahap' dalam bahasa Indonesia. Frasa ini juga terrnasuk frasa endosentrik koordinatif aditif karena mempunyai dua unsur inti dan mempunyai preposisi by 'demi'. Frasa step by step pada konteks data (19) untuk menggambarkan pelaksanaan pembangunan secara tahap demi tahap karena dana yang dimiliki terbatas sehingga tidak cukup kalau dilaksanakan sekaligus. 
Frasa sense of crisis pada data (20) mempunyai pengertian 'kepekaan terhadap masalah'. Frasa tersebut termasuk frasa endosentrik atributif dengan unsur inti sense dan atribut crisis serta mengandung preposisi of 'terhadap'. Frasa sense of crisis pada konteks data (20) untuk menggambarkan kondisi para wakil rakyat yang duduk di DPRD pada masa reformasi ini tidak mempunyai kepekaan terhadap berbagai permasalahan yang muncul di masyarakat. Padahal, sebagai wakil rakyat mereka harus mempunyai kepekaan terhadap apa yang dirasakan oieh masyarakat yang mereka wakili.

Frasa door to door dan up to date pada data (21) dan (22) termasuk tipe frasa endosentrik koordinatif aditif. Frasa door to door mempunyai pengertian 'pintu ke pintu'. Frasa ini pada konteks data (21) digunakan untuk menunjukkan cara pemasaran dari rumah yang satu ke rumah yang lain. Frasa up to date pada data (22) mempunyai pengertian 'sesuai perkembangan zaman' atau 'mutakhir'. Pada konteks data (22) frasa ini digunakan oieh penutur (Rektor Unnes) untuk menunjukkan belum dimilikinya sarana dan prasarana mutakhir oleh sekolah-sekolah kejuruan.

Berdasarkan uraian di atas, frasa fit and proper test, like and dislike, step by step, sense of crisis, door to door, dan up to date pada data (17) - (22) identik dengan 'uji kesiapan dan kelayakan', 'suka dan tidak suka', 'tahap demi tahap', 'kepekaan terhadap masaiah', 'pintu ke pintu', dan 'mutakhir'. Jadi, data (17) - (22) dapat diubah menjadi (17a) - (22a) berikut

(17a) Sutiatmoko dari Presidium Formas menjeiaskan pejabat yang dipromosikan dengan perlakuan istimewa itu perlu menjalani uji kesiapan dan kelayakan.

(18a) Menurut dia, penempatan pegawai seharusnya berdasarkan kompetensi dan kapabilitas, bukan suka dan tidak suka

(19a) Karena keterbatasan dana, pelaksanaannya tahap demi tahap.

(20a) DPRD dinilai tidak memiliki kepakaan terhadap masalah.

(21a) Beberapa tetangga membantu memasarkan pintu ke pintu.

(22a) Dia mencontohkan sebagian besar sekoiah kejuruan belurn memiliki sarana dan prasarana mutakhir.

\section{Bentuk Baster}

Unsur campur kode ada juga yang berwujud bentuk baster. Menurut Sutanto (1995:126) bentuk baster adalah bentuk yang tidak asli. Bentuk baster dalam campur kode takserumpun menunjuk kata berimbuhan yang kata dasarnya dari bahasa asing dan mendapat imbuhan dari bahasa Indonesia. Hal ini berbeda dengan bentuk baster dalam campur kode serumpun. Dalam campur kode serumpun kata dasarnya dari bahasa daerah, sedangkan dalam campur kode takserumpun kata dasarnya dari bahasa asing. 
Adanya unsur campur kode takserumpun berupa bentuk baster dapat dilihat pada data berikut.

(23) Menurut Kapolsekta Serengan, Kamiran yang memimpin operasi itu, kecurigaan petugas diawaii dengan kedatangan Novita yang mem-booking kamar di hotel berbintang itu, Senin sore lalu sekitar pukui 16.00. (SM, 10-10-2001, XVIII).

(24) Karena itu, jika hal itu di-support dengan penambahan alat-alat modern, Lokananta bisa memproduksi aneka macam. (SM, 1-62001, XVI).

(25) Selebaran itu dilengkapi foto diri keempat anggota FPDI-P yang di-wanted (SM, 20-1-2001, XVII).

(26) Itu saja yang tidak ter-cover pasti lebih banyak. (SM, 10-102001, XV).

(27) Jika pengeloiaan diserahkan ke Pemprov, lanjutnya, pihaknya akan tetap menggunakan potensi sumber daya lama karena dinilai prospek marketing-nya cukup bagus. (SM, 1-6-2001, XVI).

(28) Dua pejabat Pemkot, Bagawat dan Budi, sudah dikenai sanksi pe-nonjob-an dan penundaan kenaikan pangkat setahun oleh Wali Kota R. Fahriyanto karena terlibat penjualan tanah Pendem. (SM, 20-7-2001, XV).

Pada data (23) - (28) unsur campur kode yang berupa bentuk baster adalah mcmbooking, di-support, di-mark-up, di-wanted, tef-cover, marketing-nya, dan pe-nonjob-an. Bentuk mem-booking pada data (23) terdiri dari dua unsur, yaitu kata booking dari bahasa Inggris dan awalan meN- dari bahasa Indonesia. Pemakaian kata mem-booking pada konteks data tersebut tidak mutlak karena kata tersebut mempunyai padanan 'memesan'. Pemakaian kata mem-booking didukung oleh konteks lokasi yaitu hotel berbintang dan kata tersebut lazim digunakan untuk pemesanan kamar.

Kata di-support dan di-wanted 'didukung' dan 'dicari' pada data (24) dan (25) terdiri atas dua unsur, yaitu kata support dan wanted dari bahasa Inggris dan awalan di- dari bahasa Indonesia, Pemakaian kedua kata ini pada konteks kedua data di atas tidak mutlak karena dalam bahasa Indonesia sudah ada padanannya. Kata di-support berpadanan dengan kata 'didukung' dan kata di-wanted berpadanan dengan kata 'dicari'.

Pada data (26) kata ter-cover juga terdiri atas dua unsur, yaitu kata cover yang berasal dari bahasa Inggris dan awalan ter- yang berasal dari bahasa Indonesia. Kata tercover pada konteks data (26) bermakna 'terlayani/terjangkau'. Penutur menggunakan bentuk itu untuk menunjukkan kemampuan dan kebanggaannya menggunakan kata dari bahasa asing.

Berbeda dengan data (23) - (27), pada data (28) unsur campur kode yang berupa 
bentuk baster bentuk dasarnya tidak mendapat awalan tetapi mendapat akhiran. Pada data (28) kata marketing-nya terdiri atas dua unsur, yaitu kata marketing dari bahasa Inggris dan akhiran -nya dari bahasa Indonesia. Pemakaian kata marketing-nya lazim digunakan dalam dunia bisnis, tetapi pemakaian kata tersebut pada konteks data (28) sebenarnya dapat digantikan dengan kata 'pemasarannya'.

Pada data (28) unsur campur kode yang berupa bentuk baster bentuk dasarnya tidak hanya mendapat awalan atau pun akhiran, tetapi mendapat awalan sekaligus akhiran secara bersama-sama. Kata pe-nonjob-an terdiri atas dua unsur, yaitu kata nonjob dari bahasa Inggris dan konfiks peng-/-an dari bahasa Indonesia, Kata pe-nonjob-an berarti 'pembebastugasan dari jabatan yang diemban/diampu'. Pada konteks data (28) kata ini digunakan untuk menunjukkan dua pejabat Pemkot Magelang terlibat kasus penjualan tanah Pendem sehmgga dibebastugaskan oleh Walikota dari jabatan yang diemban.

Berdasarkan uraian di atas, bentuk baster mem-booking, di-support, di-mark-up, diwanted, ter-cover, marketing-nya, dan pe-nonjob-an identik dengan kata 'memesan', 'didukung', 'dinaikkan', 'dicari', 'terlayani/terjangkau', 'pemasarannya', dan 'pembebastugasan'. Oleh karena itu data (23)-(28) dapat diubah menjadi (23a)- (28a) berikut.

(23a)Menurut Kapolsekta Serengan, Kamiran yang memimpin operasi itu, kecurigaan petugas diawali dengan kedatangan Novita yang memesan kamar di hotel berbintang itu, Senin sore lalu sekitar pukul 16.00.

(24a) Karena itu, jika hal itu didukung dengan penambahan alat-alat modern, Lokananta bisa memproduksi aneka macam.

(25a) Selebaran itu dilengkapi foto diri keempat anggota FPDI-P yang dicari.

(26a) Itu saja yang tidak terlayani pasti lebih banyak.

(27a) Jika pengelolaan diserahkan ke Pemprov, lanjutnya, pihaknya akan tetap menggunakan potensi sumber daya larna karena dinilai prospek pemasarannya cukup bagus.

(28a) Dua pejabat Pemkot, Bagawat dan Budi, sudah dikenai sanksi pembebastugasan dan penundaan kenaikan pangkat setahun oleh Wali Kota H. Fahriyanto karena terlibat penjualan tanah Pendem.

\section{Idiom}

Campur kode taksemmpun dapat juga berupa idiom. Sama halnya dengan campur kode serumpun, berdasarkan data idiom yang ada dalam campur kode takserumpun juga hanya idiom penuh, sedangkan jenis lain tidak ada. Idiom dalam campur kode takserumpun berdasarkan data hanya ada yang berasal dari bahasa Inggris, sedangkan dari bahasa Arab dan Belanda tidak ada. Data (29) - (33) berikut menunjukkan adanya hal tersebut. 
(29) Jika ingin menyelesaikan kasus sepeda motor Dewan secara win-win solution, seharusnya pimpinan Dewan terlebih dahulu menciptakan hubungan harmonis dengan semua pihak. (SM, 3012-2001, III).

(30) Koperasi yang menunggak akan masuk black list. (SM, 30-12001, XVII).

(31) Dia berharap seluruh elemen gerakan mahasiswa, masyarakat, dan elite politik cooling down. (SM, 30-3-2001, XV).

(32) Dia menyatakan rnendukung dan pernah mengusulkan adanya sistem knockdown yangkini telah menjadi ketentuan. (SM, 1-92001, XVI).

(33) DPRD menunda pembentukan organisasi perizinan itu karena pembahasan mengalami deadlock. (SM, 10-3-2001, XIV).

Pada data (29) terdapat idiom win-win solution. Idiom win-win solution bermakna 'melegakan semua pihak'. Dalam konteks data tersebut, digunakan untuk menunjukkan tidak adanya pihak yang kalah dan yang menang dalam kasus pengadaan sepeda motor untuk anggota Dewan.. Idiom black list pada data (30) mempunyai padanan dalam bahasa Indonesia 'daftar hitam'. Maksud idiom black list dalam konteks data tersebut adalah untuk menunjukkan koperasi yang berkondite jelek.

Idiom yang terdapat pada data (31) adalah cooling down. Idiom ini bermakna 'menenangkan diri' atau 'menahan diri'. Dalam konteks data (31) idiom cooling down digunakan untuk menyatakan bahwa seluruh elemen gerakan dalam masa reformasi harus menahan diri dengan cara tidak memanas-manasi gerakan lain atau memanaskan suhu politik yang sudah cukup panas.

Pada data (32) terdapat idiom knock down. Idiom ini bermakna 'bongkar pasang' dalam bahasa Indonesia. Pada konteks tersebut idiom knock down digunakan untuk menyatakan perlunya pemakaian sistem 'bongkar pasang' dalam pembangunan kios-kios untuk pedagang kaki lima. Jadi, kios yang dibangun harus dapat dibongkar pasang dan bukan berupa bangunan permanen.

Idiom dead lock terdapat pada data (33), Idiom ini bermakna 'jalan buntu'. Idiom dead lock biasa digunakan untuk menunjukkan tidak tercapainya kesepahaman atau pemecahan dalam pembahasan suatu masalah. Pada konteks data (33) idiom dead lock menunjukkan tidak tercapainya kesepakatan antaranggota DPRD dalam pembentukan organisasi perizinan.

Dari uraian di atas dapat dilihat bahawa idiom win-win solution, black list, cooling down, knock down dan deadlock identik dengan 'melegakan semua pihak', 'daftar 
hitam', 'menenangkan diri', 'bongkar pasang', dan 'jalan buntu'. Oleh karena itu, data (29) (33) dapat diubah menjadi (39a) - (33a) berikut

(29a)Jika ingin menyelesaikan kasus sepeda motor Dewan secara meiegakan semua pihak, seharusnya pimpinan Dewan terlebih dahulu menciptakan hubungan harmonis dengan semua pihak.

(30a) Koperasi yang menunggak akan masuk daftar hitam.

(31a) Dia berharap seluruh elemen gerakan mahasiswa, masyarakat, dan elite politik menahan diri.

(32a) Dia menyatakan mendukung dan pernah mengusulkan adanya sistem bongkar pasang yang kini telah menjadi ketentuan.

(33a) DPRD menunda pembentukan organisasi perizinan itu karena pembahasan mengalami jalan buntu.

\section{Simpulan}

Berdasarkan bahasa sumbernya, campur kode dalam wacana berita daerah harian Suara Merdeka dapat dibagi menjadi dua jenis, yaitu campur kode serumpun dan campur kode takserumpun. Dalam campur kode takserumpun, antara bahasa sumber dan bahasa sasaran tidak mempunyai hubungan, baik secara geografis maupun genetis. Jadi, secara geografis bahasa-bahasa tersebut dipergunakan sebagai pengantar dalain wilayah politis yang berbeda, Demikian pula dilihat dari hubungan kekerabatannya, bahasa-bahasa yang terlibat dalam campur kode itu tidak berhubungan. Wujud campur kode takserumpun yang terdapat dalam wacana berita daerah harian Suara Merdeka dapat berupa kata, frasa, bentuk baster, idiom, dan klausa.

\section{Daftar Pustaka}

Alwasilah, Chaedar. 1985. Sosiologi Bahasa. Bandung: Angkasa.

Kridalaksana, Harimurti. 1982. Fungsi Bahasa dan Sikap Bahasa. Ende-FIores: Nusa Indah.

Nababan, P.W.J. 1986. Sosiolinguistik: Suatu Pengantar. Jakarta: PT Gramedia.

Poedjosoedarmo, Soepomo. 1986. Sosiolinguistik. Yogyakarta: Fak. Pasca-sarjana Ilmu-ilmu Humaniora.

Sudaryanto. 1993 Metode dan Aneka Teknik Analisis Bahasa: Pengantar

Penelitian Wahana Kebudayaan secara Linguistis. Yogyakarta: Duta Wacana University Press.

Suwito. 1985. Pengantar Awal Sosiolinguistik, Teori dan Problema. Surakarta: Henary Offset. 